\title{
Factors Affecting Debt Maturity Structure: Evidence from Listed Enterprises in Vietnam*
}

\author{
Duong Thuy PHAN ${ }^{1}$
}

Received: July 18, 2020 Revised: August 23, 2020 Accepted: August 28, 2020

\begin{abstract}
This paper analyzes factors affecting the debt maturity structure of enterprises listed on the Vietnam stock market. The panel data of research sample includes 549 non-financial listed enterprises on the Vietnam stock market from 2009 to 2019. The Generalized Least Square (GLS) tool is employed to address econometric issues and to improve the accuracy of the regression coefficients. In this research, debt maturity structure is the dependent variable. Capital structures, fixed assets, liquidity, firm size, asset maturity, profitability, corporate income tax, gross domestic product, inflation rate, credit growth scale are independent variables in the study. The model results show, that among the factors affecting the structure of debt maturity, the capital structure, asset structure, and firm size have the highest estimation coefficients, which shows that capital structure, asset structure, and firm size plays an important role in the decision-making process of debt maturity structure. The empirical results show that there are differences in the impact of these factors on the debt maturity structures in state-owned enterprises and non-state enterprises listed on the Vietnam stock market. The findings of this article are useful for business administrators, helping business managers make the right financial decisions to determine the target debt maturity structure in enterprises.
\end{abstract}

Keywords: Debt Maturity Structures, State-Owned Enterprises, Non-State Enterprises, Vietnam

JEL Classification Code: G30, M40, M41

\section{Introduction}

The structure of the debt maturity is the relationship between the short-term debt and the long-term debt, in which, long-term debt is the debt with a maturity of more than one year and short-term debt. Debts are loans with a due maturity of 12 months (Barclay \& Smith, 1995). Therefore, the structure of corporate debt maturity has a certain influence on the sustainable development as well as business performance of the enterprise (Modigliani \& Miller, 1958; Myers \& Majluf, 1984). Therefore, the pursuit of debt

\footnotetext{
*Acknowledgements:

The author is thankful to University of Transport Technology for funding this research. I would like to thank the anonymous referees for their helpful comments and suggestions.

${ }^{1}$ First Author and Corresponding Author. Faculty of Transport Economics, University of Transport Technology, Vietnam [Postal Address: 54 Trieu Khuc Street, Thanh Xuan District, Hanoi, 100000, Vietnam] Email: duongpt@utt.edu.vn

(C) Copyright: The Author(s)

This is an Open Access article distributed under the terms of the Creative Commons Attribution Non-Commercial License (https://creativecommons.org/licenses/by-nc/4.0/) which permits unrestricted non-commercial use, distribution, and reproduction in any medium, provided the original work is properly cited.
}

maturity structure that does not match the characteristics of the business sector and the characteristics of each business can lead to long-term disadvantages for the business. According to the fit theory, the debt structure imbalance will reduce the business performance of enterprises (Morris, 1976; Stohs \& Mauer, 1996).

The study of debt maturity structure focuses on verifying and explaining decisions on the selection of debt maturity structure of businesses. The first studies on the structure of debt maturities from the 1980s to the mid-1990s included Barnea et al. (1980), Brick and Ravid (1985), Flannery (1986), Barclay and Smith (1995), Diamond (1991), Stohs and Mauer (1996), Ooi (1999). Most of these studies have focused on debt structure of businesses in developed countries. The first studies supporting the use of short-term debt by businesses include the research of Flannery (1986), Jayat and Thomas (1990), Ooi (1999), Myers (1977), Barnea et al. (1980). Research supporting the use of long-term debt by businesses includes research by Brick and Ravid (1985; 1991), Stohs and Mauer (1996) and recently spread to emerging economies such as Research by Cai et al (2008), Deesomsak et al. (2009), Terra (2011), Stephan et al. (2011), Lemma and Negash 
(2012) mainly researches debt structure of industries, electronics engineering.

Vietnam's economy is gradually transforming and developing. The financial market has not been fully developed, with many limitations, so the issue of debt maturity structure of listed companies in Vietnam becomes more complicated. Because the debt market in Vietnam is too new, studies on the selection of debt term structure are still limited. On the other hand, the Government of Vietnam still holds a large portion of ownership in previous stateowned economic enterprises/large state-owned corporations as well as companies in strategic fields, such as quarrying and quarrying, electricity, oil and gas. This practice raises questions about the influence of state ownership on the operation of enterprises and the structure of debt maturity in the Vietnamese context.

This article analyzes the influence of factors on the structure of debt maturity of enterprises listed on Vietnam's stock market in the period of 2009-2019. The results of the study will be useful for business executives and policy makers in financial management.

\section{Literature Review and Hypotheses}

\subsection{Study Overview}

\subsubsection{The Structure of Debt Maturity}

Equilibrium theory. From the viewpoint of equilibrium theory, choosing the optimal debt term, businesses must consider the balance between benefits from tax shield and issuance cost, bankruptcy cost. The cost of paying short-term debt due to borrowing is higher than the long-term debt for reinvestment. In addition, businesses will choose short-term debt over long-term debt because they are assessed financial health based on asymmetric information (Brick \& Ravid, 1985; Brick \& Ravid, 1991)

Theory of agency costs. The representative costs of equity arise due to the information asymmetry between the company manager and the business owner, between the shareholders and the company executive, between the major shareholders and minority shareholders. According to the representative cost theory, businesses choose debt terms to minimize representation costs. There are two cases of the representative issue of equity, which makes the cost of representation increase due to "underinvestment" or "overinvestment". Barnea et al. (1980) stated that enterprises choose to use short-term debt term or long-term debt term for investment projects, if using reasonable debt term will minimize conflicts and conflicts between shareholders and bondholders. Terra (2011) argues that small-sized companies often increase the use of short-term debt for investments, so these businesses incur higher agency costs due to underinvestment, increase conflict between managers and shareholders.
Signal theory. Debt maturity structure is considered as a tool to resolve representative conflicts, businesses must give signals about the current financial situation to ensure the ability to repay debt. Signals from asymmetric information imply that businesses choose debt terms such as signaling to the market and managers are always better informed than outside investors about the health of their debt financial health of businesses (Diamond, 1991; Flannery, 1986; Stohs and Mauer, 1996).

Theory of taxes. Taxes have a relationship between choosing short-term debt and long-term debt, the optimal structure of debt maturity structure is the tradeoff between the benefits of tax shield for corporate debt industry and the disadvantages of agency costs. The term structure of interest rates decreases, firms will decide to choose long-term debt (Brick and Ravid, 1985; Brick and Ravid, 1991; Stephan et al., 2011).

\subsubsection{Empirical Research on Debt Structure}

There have been many works in the world studying the factors affecting the structure of corporate debt maturities and using theories related to the structure of debt maturity to explain the choice of debt maturity of businesses. Most of these studies focused on a number of issues related to corporate debt tenors as follows:

Firstly, debt maturity structure of the firm is affected by micro factors. The study of debt maturity structure shows the factors that express the unique characteristics of each enterprise such as debt ratio, profit, income fluctuation, liquidity, tangible assets, asset maturity, firm size, growth opportunities, and taxes also affect the firm's debt maturity structure. However, the degree of impact as well as the direction of impact are not the same among different countries, this depends on the economic context of each country studied. Empirical research results obtained in AsiaPacific, Eastern Europe and South American countries are quite compatible. Accordingly, debt ratio, liquidity, and firm size are positively correlated with the structure of debt maturity, while the remaining intrinsic factors such as profit, income fluctuations, tangible assets, the asset maturity, growth opportunities, and tax resulting in an impact on debt structure are not clear. The results of the research provided solid evidence for arguments based on representation cost theory and conformity theory, but did not provide enough evidence for arguments based on signal theory and tax-based theory (Ozkan, 2000; Teruel \& Solano, 2007; Terra, 2011; Mateurs \& Terra, 2013; Hussain et al, 2018).

Secondly, debt maturity structure of the firm is affected by macro factors. The studies of Demirguc-Kunt and Maksimovic (1999), Fan et al. (2012), Kirch and Terra (2012), Correia et al. (2014) also consider issues related to institution, law or scale of financial center and corporate income tax system. The research results show that in the 
same country, changes of macro environment and national orientation in different periods also affect the selection of debt structure of enterprises. Wang et al. (2010) show that there exists a relationship between debt maturity structure and economic indicators such as economic growth, inflation, money supply and corporate income tax. In addition, the maturity structure of businesses in China is affected by internal factors such as firm size, asset maturity and growth opportunities. Specifically, factors such as corporate income tax, growth rate (GDP) have a positive relationship with the structure of debt maturities, which implies that the more the economy grows along with business activities of enterprises, the business will use more long-term debt. In contrast, when inflation and money supply increase, enterprises use more short-term debts.

\subsection{Research Hypotheses}

Based on the theoretical and empirical research on debt structure, the author established 10 research hypotheses on factors affecting the debt structure of Vietnamese businesses listed on the market as follows:

$\boldsymbol{H}_{1}$ : Capital structure has a positive (+) effect on the debt maturity structure of the firm.

$\boldsymbol{H}_{2}:$ Asset structure has a positive (+) effect on the debt maturity structure of the firm.

$\boldsymbol{H}_{3}:$ Liquidity has a positive (+) effect on the debt maturity structure of the firm.

$\boldsymbol{H}_{4}$ : Firm size has a positive (+) effect on the debt maturity structure of the firm.

$\boldsymbol{H}_{5}:$ Asset maturity has a positive (+) effect on the debt maturity structure of the firm.
$\boldsymbol{H}_{6}:$ Profitability has a negative impact (-) on the debt maturity structure of the firm.

$\boldsymbol{H}_{7}:$ Corporate income tax has a positive (+) effect on the debt maturity structure of the firm.

$\boldsymbol{H}_{\boldsymbol{8}}$ : Economic growth has a positive (+) effect on the debt maturity structure of the firm.

$\boldsymbol{H}_{9}$ : Inflation rate has a positive (+) effect on the debt maturity structure of the firm.

$\boldsymbol{H}_{10}:$ Credit growth scale has a positive (+) effect on the debt maturity structure of the firm.

\section{Model and Research Method}

\subsection{Research model}

The model to study the factors affecting the structure of debt maturity of businesses listed on Vietnam's stock market is based on the research models of Ozkan (2000); Antoniou et al. (2006), Cai et al. (2008), Deesomsak et al. (2009), Terra (2011), Fan et al. (2012), Krich and Terra (2012), Alcock et al. (2014), Alves and Francisco (2015), Hussain et al. (2018).

$$
\text { LDRit }=\beta 0+\beta x X i t+\beta z Z t+\text { eit }
$$

Dependent variable: Structure of debt maturity (LDR) The independent variable consists of 9 variables:

Variables (Xit): Capital structures (TDR), fixed assets (TANG), liquidity (LIQ), firm size (SIZE), corporate income tax (TAX), asset maturity (AMR), profitability (ROE);

The variable $(\mathrm{Zt})$ includes variables: real economic growth (GDP), inflation rate (INF), credit growth scale (CREDIT)

eit is the error.

Table 1: Description of variables in the research model

\begin{tabular}{|l|c|l|c|}
\hline Variable name & Code & \multicolumn{1}{|c}{ Notes } & Expectations \\
\hline Debt maturity structures & LDR & Long-term debt / total debt & + \\
\hline Capital structures & TDR & total debt / total assets & + \\
\hline Fixed assets & TANG & Fixed assets / total assets & + \\
\hline Liquidity & LIQ & Current assets / current liabilities & + \\
\hline Firm size & SIZE & Ln(total assets) & + \\
\hline Asset maturity & AMR & $\begin{array}{l}\text { [Current assets/( Current assets+ Fixed assets)] } \text { Current } \\
\text { assets/ Cost of goods sold +[Fixed assets /( Current assets } \\
+ \text { Fixed assets)]x Fixed assets/ depreciation }\end{array}$ & + \\
\hline Profitability & ROE & Net income/ Average equity & + \\
\hline Corporate income tax & TAX & Corporate income tax / profit before tax & + \\
\hline Gross Domestic Product & GDP & GSO Vietnam & + \\
\hline Inflation rate & INF & GSO Vietnam & + \\
\hline Credit growth scale & CREDIT & GSO Vietnam & + \\
\hline
\end{tabular}




\subsection{Research data}

The study used panel data collected from 549 nonfinancial enterprises listed on the Vietnam stock market over an eleven years period, from 2009 to 2019 , provided by FiinGroup JSC. Research data is extracted from the audited financial statements of these enterprises. The sample includes 284 state-owned enterprises and 265 non-state enterprises.

\subsection{Research method}

The baseline analysis was first performed to screen the sample, to eliminate observations that were too large, too small, or too different from the sample size. This basic analysis step helps to check the suitability of the sample before performing regression analysis OLS, FEM, REM, to ensure the reliability of quantitative research results. Specifically, the author conducts statistical description analysis, correlation analysis to eliminate multi-collinear phenomena between independent variables. After selecting the appropriate method to run the model, the author examines the variance of variance, multicollinearity, autocorrelation, endogeneity of the model. In case the model has a defect, the author will use the FGLS (Feasible generalized least squares) method to overcome.

\section{Empirical Results}

The empirical results of factors affecting debt maturity structures in state-owned enterprises are shown in Table 2. We compare and choose which model is suitable model is FEM or REM. To consider and select the appropriate model between the two regression methods, the author uses the Hausman test.

Multicollinearity test results show that the magnification coefficient of VIF variance are $<10$, the model has no multicollinearity phenomenon. The mean VIF is 1.17, which indicates that the possibility of multicollinearity is not significant. The White test indicates that the model has heterogeneity ( $\mathrm{p}$-value $<5 \%$ ) and the Breusch and Pagan Lagrangian Multiplier test for random effects results (Table 2) rejected the null hypothesis that the Pooled OLS model was appropriate. Following the results from the Hausman test $(\mathrm{P}$-value $=0.0000<0.05)$, selecting the appropriate model is FEM, the author proceeds to overcome the discovered defects of the model by FGLS method.

The empirical results of factors affecting debt maturity structures in non-state enterprises are shown in Table 3. As the results of regression analysis show that the value of VIF coefficient is less than 10, there is multi-collinear phenomenon. The maximum VIF is 1.13 , which indicates that the possibility of multicollinearity is not significant.

Table 2: Regression results of state-owned enterprises

\begin{tabular}{|c|c|c|c|c|}
\hline \multirow{2}{*}{ Variable } & \multirow{2}{*}{ VIF } & \multicolumn{3}{|c|}{ Regression coefficients } \\
\hline & & POLS & FEM & REM \\
\hline TDR & 1.43 & $0.116^{* * *}$ & $0.296^{* * *}$ & $0.234^{* * *}$ \\
\hline TANG & 1.05 & $0.487^{* * *}$ & $0.278^{* * *}$ & $0.334^{* * *}$ \\
\hline LIQ & 1.29 & $0.00596^{* * *}$ & $0.00348^{* * *}$ & $0.00358^{* * *}$ \\
\hline SIZE & 1.18 & $0.0448^{* * *}$ & $0.0297^{* * *}$ & $0.0419^{* * *}$ \\
\hline AMR & 1.05 & $0.000863^{* * *}$ & 0.00000205 & 0.0000910 \\
\hline ROE & 1.13 & $-0.104^{* * *}$ & -0.0299 & $-0.0342^{*}$ \\
\hline TAX & 1.01 & $-0.0231^{\star *}$ & $-0.0114^{*}$ & $-0.0126^{*}$ \\
\hline GDP & 1.21 & $-0.0103^{*}$ & $-0.00737^{*}$ & $-0.00909^{* *}$ \\
\hline INF & 1.20 & $0.00272^{\star * *}$ & $0.00194^{\star * *}$ & $0.00223^{* * *}$ \\
\hline CREDIT & 1.13 & $0.00186^{\star * *}$ & $0.00161^{* * *}$ & $0.00177^{* * *}$ \\
\hline Cons & & $-1.168^{* * *}$ & $-0.823^{* * *}$ & $-1.125^{\star * *}$ \\
\hline $\mathrm{N}$ & & 3123 & 3123 & 3123 \\
\hline R-sq & & 0.335 & 0.133 & \\
\hline Significance & & $F(10,3112)=157.02$ & $F(10,2828)=43 \cdot 30$ & Wald chi2 $(10)=597.62$ \\
\hline White test & & \multicolumn{3}{|c|}{ Chi2 (65) = 1517.44} \\
\hline LM test & & \multicolumn{2}{|c|}{ Chi2 $(285)=6.3 e+05$} & 0.0000 \\
\hline Hausman test & & \multicolumn{2}{|c|}{ Chi2(10) = 59.13} & 0.0000 \\
\hline Wooldridge test & & \multicolumn{2}{|c|}{$F(1,284)=285.424$} & 0.000 \\
\hline
\end{tabular}

Note: $\left({ }^{*}\right),\left({ }^{* *}\right),\left({ }^{* * *}\right)$ represent for the significant level at $1 \%, 5 \%$ and $10 \%$, respectively 
Table 3: Regression results of non-state-owned enterprises

\begin{tabular}{|c|c|c|c|c|}
\hline \multirow{2}{*}{ Variable } & \multirow{2}{*}{ VIF } & \multicolumn{3}{|c|}{ Regression coefficients } \\
\hline & & POLS & FEM & REM \\
\hline TDR & 1.31 & $0.126^{* * *}$ & $0.140^{* * *}$ & $0.139^{* * *}$ \\
\hline TANG & 1.04 & $0.312^{* * *}$ & $0.183^{* * *}$ & $0.211^{* * *}$ \\
\hline LIQ & 1.18 & $0.00176^{* * *}$ & $0.00180^{* * *}$ & $0.00179^{* * *}$ \\
\hline SIZE & 1.22 & $0.0476^{* * *}$ & $0.0728^{* * *}$ & $0.0621^{* * *}$ \\
\hline AMR & 1.01 & 0.0000628 & 0.00000570 & 0.00000898 \\
\hline ROE & 1.04 & $-0.0385^{\star * *}$ & $-0.0299^{* * *}$ & $-0.0296^{\star * *}$ \\
\hline TAX & 1.01 & -0.00151 & $-0.0230^{* *}$ & $-0.0218^{\star *}$ \\
\hline GDP & 1.23 & -0.00794 & $-0.0158^{* * *}$ & $-0.0125^{\star * *}$ \\
\hline INF & 1.19 & $0.00190^{* *}$ & $0.00249^{* * *}$ & $0.00220^{* * *}$ \\
\hline CREDIT & 1.11 & $0.00135^{\star \star *}$ & $0.00172^{\star \star \star}$ & $0.00152^{* * *}$ \\
\hline Cons & & $-1.225^{\star \star \star}$ & $-1.856^{* * *}$ & $-1.582^{\star * *}$ \\
\hline $\mathrm{N}$ & & 2917 & 2917 & 2917 \\
\hline R-sq & & 0.177 & 0.116 & \\
\hline Significance & & $F(10,2906)=62.62$ & $F(10,2640)=34.48$ & Wald chi2 $(10)=396.81$ \\
\hline White test & & \multicolumn{3}{|c|}{ Prob $>$ Chi2 $=0.0000$} \\
\hline LM test & & \multicolumn{2}{|c|}{$\operatorname{chi} 2(267)=6.9 \mathrm{e}+05$} & 0.0000 \\
\hline Hausman test & & \multicolumn{2}{|c|}{ Chi2 $(10)=28.80$} & 0.0013 \\
\hline Wooldridge test & & \multicolumn{2}{|c|}{$F(1,266)=99.158$} & 0.000 \\
\hline
\end{tabular}

Note: $\left({ }^{*}\right),\left({ }^{* *}\right),\left({ }^{* *}\right)$ represent for the significant level at $1 \%, 5 \%$ and $10 \%$, respectively

Table 4: FGLS regression results of model

\begin{tabular}{|l|c|c|}
\hline Variable & $\begin{array}{c}\text { State-owned } \\
\text { enterprises }\end{array}$ & $\begin{array}{c}\text { Non state-owned } \\
\text { enterprises }\end{array}$ \\
\hline TDR & $.0325372^{*}$ & $.0483978^{* * *}$ \\
\hline TANG & $.3580144^{* * *}$ & $.220565^{* * *}$ \\
\hline LIQ & $.0041674^{* * *}$ & $.0003066^{*}$ \\
\hline SIZE & $.0301312^{* * *}$ & $.0358133^{* * *}$ \\
\hline AMR & $.0003588^{* *}$ & $1.42 \mathrm{e}-06$ \\
\hline ROE & -.0087013 & -.0119557 \\
\hline TAX & .0001358 & -.001508 \\
\hline GDP & .0002395 & .0025287 \\
\hline INF & $.0012291^{* * *}$ & .0009842 \\
\hline CREDIT & $.0009693^{* * *}$ & $.00125^{* * *}$ \\
\hline Cons & $-.8189765^{* * *}$ & $-.9749553^{* * *}$ \\
\hline
\end{tabular}

Note: $\left.\left({ }^{*}\right),{ }^{* *}\right),\left(^{* * *}\right)$ represent for the significant level at $1 \%, 5 \%$ and $10 \%$, respectively
The White test indicates that the model has heterogeneity ( $\mathrm{p}$-value $<5 \%$ ) and the Breusch and Pagan Lagrangian Multiplier test for random effects results (Table 3) rejected the null hypothesis that the Pooled OLS model was appropriate. Following the results from the Hausman test $(\mathrm{P}$-value $=0.0013<0.05)$, selecting the appropriate model is FEM, the author proceeds to overcome the discovered defects of the model by FGLS method.

Regression model results according to FGLS method show:

For state-owned enterprises: the variables TANG, LIQ, SIZE, INF and CREIT are the positive factors affecting LDR with $1 \%$ significance level and the impact level is $35.8 \%, 4.16 \%, 30.13 \%, 1.23 \%$ and $0.9 \%$. Besides, the AMR variable positively affects LDR at $0.36 \%$ with $5 \%$ significance level, the TDR variable positively affects the debt maturity structure at $32.53 \%$ with significant $10 \%$. The remaining factors including ROE, TAX, GDP are not statistically significant.

For non state enterprises: the variables TDR, TANG, SIZE, INF and CREIT are the positive factors affecting LDR with $1 \%$ significance level and $44.8 \%$, respectively. $22.06 \%$, 
$3.58 \%, 1 \%$ and $1.25 \%$. In addition, the variable LIQ positively impacted the structure of debt maturity at $0.31 \%$ with a significant level of $10 \%$. The remaining factors including AMR, ROE, TAX, and GDP are not statistically significant.

\section{Discussion and Recommendations}

\subsection{Discussion}

The regression results in Table 4 show that the factors affecting the structure of debt maturity for the group of enterprises with state capital and the group of enterprises that do not have state capital under the FGLS method provide evidence:

Capital structure (TDR): has a positive impact on debt structure in accordance with the research hypotheses of Kirch and Terra (2012), Duan and Chik (2012), Alves and Francisco (2015), Belkhir et al. (2016).

Asset structure (TANG): has a positive impact on debt structure in accordance with the research hypotheses, works of Kirch and Terra (2012), Duan and Chik (2012), Alves and Francisco (2015), Belkhir et al. (2016). According to the theory of suitability, in order to minimize the risk and costs of financial exhaustion, the maturity of debt must be consistent with the maturity of assets in the enterprise, firms with more tangible assets may have better collateral, lower bankruptcy costs, and therefore may borrow more for longer terms (Krich \& Terra, 2012).

Liquidity (LIQ): has a positive impact on debt structure in accordance with the research hypotheses of Cai et al (2008), Deesomsak et al. (2009), Mateurs and Terra (2013). This implies that businesses with high liquidity will easily raise long-term capital.

Firm size (SIZE): has a positive impact on debt structure in accordance with research hypotheses, works of Cai et al (2008), Correia et al. (2014), Deesomsak et al. (2009), Duan and Chik (2012), Alves and Francisco (2015), Belkhir et al. (2016). This implies that large-scale enterprises are able to mobilize long-term loans and vice versa, small-scale enterprises will face many limitations when accessing the long-term loan market.

Asset structure (AMR): for the group of enterprises with state capital contribution that has the same directional impact on the debt maturity structure in accordance with the research hypotheses of Cai et al (2008), Correia et al. (2014), Deesomsak et al. (2009), Duan and Chik (2012), Alves and Francisco (2015), Belkhir et al. (2016).

Profitability (ROE), Corporate Income Tax (TAX), Economic Growth Rate (GDP): has a weak and insignificant impact on debt structure. This result is contrary to the research hypotheses and studies of Cai et al (2008), Correia et al. (2014), Deesomsak et al. (2009), Duan and Chik (2012), Alves and Francisco (2015), Belkhir et al. (2016).
Inflation (INF): has a positive impact on debt structure. This result is consistent with the research hypothesis, according to the trade-off theory and the work of Deesomsak et al (2009), Fan et al (2012), Tongkong et al. (2013), Khanna et al. (2015). This shows that, during inflation, businesses tend to use loans with longer maturities compared to short terms because long-term interest expenses are lower than short-term borrowing costs.

Among the factors affecting the structure of debt maturity, the capital structure, asset structure and firm size have the highest estimation coefficients, which shows that capital structure, asset structure and firm size plays an important role in the decision making process of debt maturity structure.

\subsection{Recommendations}

The results of analyzing the factors affecting the structure of debt maturity of businesses listed on Vietnam's stock market are based on past financial data. In accordance with the characteristics of each enterprise, it is necessary to adjust it to suit the reality. Administrators need to consider the order of priority in analyzing the factors affecting the structure of debt maturity, which factors have a strong impact and are the main and important factors in selecting period structure and target debt in each stage of development of the business. In addition, empirical research results show that the POT theory is based on information discrepancy, the TOT theory explains the funding decision of the business, and the conformity theory explains the mid-term suitability assets and debt maturity to make decisions about loan maturity. Therefore, business managers, when making the debt structure, must base it on the conditions and assumptions of the debt maturity structure theory.

In addition, corporate governance needs to consider the intrinsic characteristics of the company that have a strong impact on the debt maturity structure in order to formulate the most appropriate debt maturity policy for the company, specifically the administrator. Please note the following:

Firm size has a positive impact on the structure of debt maturity with the impact of $32.5 \%$ for state-owned enterprises and $48.4 \%$ for private enterprises. Therefore, administrators need to consider the size of the company in the future to make a reasonable debt structure. Large-scale enterprises will implement long-term debt policy accounting for a large proportion of the total debt.

Asset structure has a positive impact on the structure of debt maturity with an impact of $35.8 \%$ for stateowned enterprises and $22.1 \%$ for private enterprises. So, administrators should care about the value of a company's fixed assets. The value of fixed assets is closely related to the value of the mortgage and the value of the loan. If the company has more fixed assets, it is more likely to have long-term debt and vice versa. And the longer the asset is used, the more it should be financed with long-term loans. 


\section{Conclusion}

In summary, through a set of data collected from 284 state-owned companies and 265 non-state companies listed on Vietnam's stock market in the period of 2009-2019, the author analyzed the impact of weak factors the debt maturity structure of these two groups of companies. Empirical results from the FGLS regression show that capital structure, asset structure, firm size, inflation, and credit growth have a positive impact on the structure of debt maturity of both business groups. In addition, asset maturity has a positive effect on the structure of debt maturities of state-owned enterprises, and liquidity has a positive impact on debt structure of private enterprises. The remaining factors include profitability, corporate income tax, and economic growth rate having a weak and negligible impact on debt structure of both groups of businesses.

The findings of this article are useful for corporate executives, helping business executives determine the target debt maturity structure for businesses and make sound financial decisions to improve high business efficiency in the enterprise.

\section{References}

Alcock, J. T., Steiner, E., \& Tan, K. J. K. (2014). Joint leverage and maturity choices in real estate frms: The role of the REIT status. Journal of Real Estate Finance and Economics, 48(1), 57-78. https://doi.org/10.1007/s11146-012-9379-7

Alves, P., \& Francisco, P. (2015). The Impact of Institutional Environment in Firms' Capital Structure during the Recent Financial Crises. The Quarterly Review of Economics and Finance, 57, 129-146. https://mpra.ub.uni-muenchen.de/51300/

Antoniou, A., Guney, Y., \& Paudyal, K., (2006). The determinants of debt maturity structure: evidence from France, Germany and the UK. European Financial Management, 12, 161-194. https://doi.org/10.1111/j.1354-7798.2006.00315.x

Barclay, M. J., \& Smith, C. W. (1995). The Maturity Structure of Corporate Debt. Journal of Finance, 50(2), 609-31. https://doi. org/10.1111/j.1540-6261.1995.tb04797.x

Barnea, A, Haugen, R. A., \& Senbet, L. W. (1980). A rationale for debt maturity structure and call provisions in the agency theoretic framework. Journal of Finance, 35, 1223-1234. https://doi.org/10.1111/j.1540-6261.1980.tb02205.x

Belkhir, M., Maghyereh, A., \& Awartani, B. (2016). Institutions and corporate capital structure in the MENA region. Emerging Markets Review, 26, 99-129. https://doi.org/10.1016/j. ememar.2016.01.001

Brick, I. E., \& Ravid, S. A. (1985). On the relevance of debt maturity structure. Journal of Finance, 40, 1423-1437. https:// doi.org/10.1111/j.1540-6261.1985.tb02392.x

Brick, I. E., \& Ravid, S. A. (1991). Interest rate uncertainty and the optimal debt maturity structure. Journal of Financial and Quantitative Analysis, 26, 63-82. DOI: 10.2307/2331243
Cai, K., Fairchild, R., \& Guney, Y., (2008). Debt maturity structure of Chinese companies. Pacific-Basin Finance Journal, 16, 268-297. https://doi.org/10.1016/j.pacfin.2007.06.001

Correia, S., Brito, P., \& Brandão, E. (2014). Corporate Debt Maturity An International Comparison of Firm Debt Maturity Choices. Working Paper, School of Economics and Management, University of Porto. http://wps.fep.up.pt/wps/wp544.pdf

Deesomsak, R., Paudyal, K., \& Pescotto, G., (2009). Debt maturity structure and the 1997 Asian financial crisis. Journal of Multinational Financial management, 19, 26-42. https://doi. org/10.1016/j.mulfin.2008.03.001

Demirgiic-Kunt, A., \& Maksimovic, V. (1999). Institutions, financial markets and firm debt maturity. Journal of Financial Economics, 54, 295-336. https://elibrary.worldbank.org/doi/ abs/10.1596/1813-9450-1686

Diamond, D. W. (1991). Debt maturity structure and liquidity risk. The Quarterly Journal of Economics, 33, 341-368. https://doi. org/10.2307/2937924

Duan, H., \& Chik, A. R. (2012). Institutional Environment, Political Connection and Financial Constraints. Evidence from Private Enterprise in China. Business and Management Research, 1(1), 133-140. http://dx.doi.org/10.5430/bmr.v1n1p133

Fan, J., Titman, S., \& Twite, G. (2012). An international comparison of capital structure and debt maturity choices. Journal of Financial and Quantitative Analysis, 47(1), 23-56. https://doi. org/10.1017/S0022109011000597

Flannery, M. J. (1986). Asymmetric information and risky debt maturity choice. Journal of Finance, 41, 19-37. https://doi. org/10.1111/j.1540-6261.1986.tb04489.x

García-Teruel, P. J., \& Martínez-Solano, P. (2007). Effects of working capital management on SME profitability. International Journal of Managerial Finance. https://doi.org/10.1108/17439130710738718

Hussian, H. I., Hadi, A. R. A, Mohamed-Isa, A., Salem, M. A., Kamarudin, F., \& Jabarullah, N. H. (2018). Adjustment to target debt maturity and equity mispricing: evidence from Asia Pacific. Polish Journal of Management Studies, 17(2), 87-100. DOI 10.17512/pjms.2018.17.2.08

Jayat, R. K., \& Thomas, H. N. (1990). Risky debt maturity choice in a sequential game equilibrium. Journal of Financial Research, 13(2), 155-166. https://doi.org/10.1111/j.1475-6803.1990. tb00545.x.

Khanna, S., Srivastava, A., \& Medury, Y. (2015). The Effect of Macroeconomic Variables on the Capital Structure Decisions of Indian Firms: A Vector Error Correction Model/Vector Autoregressive Approach. International Journal of Economics and Financial, 5(4), 968-978. http:/www.ir.juit.ac.in:8080/ jspui/handle/123456789/6650

Kirch, G., \& Terra, P. R. S. (2012). Determinants of corporate debt maturity in South America: Do institutional quality and financial development matter?. Journal of Corporate Finance, 18(4), 980-993. https://doi.org/10.1016/j. jcorpfin.2012.05.004 
Lemma, T., \& Negash, M. (2012). Debt Maturity Choice of a Firm: Evidence from African Countries. Journal of Business and Policy Research, 7(2), 60-92.

Mateurs, C., \& Terra, P. (2013). Leverage and the Maturity Structure of Debt in Emerging Markets. Journal of Mathematical Finance, 3, 46-59. http://dx.doi.org/10.4236/jmf.2013.33A005

Modigliani, F., \& Miller M. H. (1958). The cost of capital corporation finance, and the theory of investment. American Economic Review, 48, 261-297. https://www.jstor.org/stable/1809766

Morris, J. (1976). An empirical investigation of the corporate debt maturity structure. Journal of Financial and Quantitative Analysis, 10(4), 539-539

Myers, S. C. (1977). Determinants of Corporate Borrowing. Journal of Financial Economics, 5(2), 147-175. https://doi. org/10.1016/0304-405X(77)90015-0.

Myers, S. C., \& Majluf, N. (1984). Corporate Financing and investment decisions when firms have information thar investors do not have. The Journal of Finance Econmics, 13, 187-221. DOI: $10.3386 /$ w1396

Ooi, J. T. L. (1999). The Debt Maturity Structure of UK Property Companies. Journal of Property Research, 16(4), 293-307. https://doi.org/10.1080/095999199368058
Ozkan,A. (2000). An Empirical Analysis of Corporate Debt Maturity Structure. Journal of European Financial Management, 6(2), 197-212. https://doi.org/10.1111/1468-036X.00120

Stephan, A., Talaverab, O., \& Andriy, T. (2011). Corporate debt maturity choice in emerging financial markets. The Quaterly Review of Economics and Finance, 51(2), 141-153. https://doi. org/10.1016/j.qref.2010.12.003

Stohs, M. H., \& Mauer, D. C. (1996). The Determinants of Corporate Debt Maturity Structure. Journal of Business, 69(3), 279-312. https://www.jstor.org/stable/2353370

Terra, P. R. S. (2011). Determinants of corporate debt maturity in Latin America. Journal of European Business Review, 23(1), 45-70. https://doi.org/10.1108/09555341111097982

Tongkong, S., \& Jantarakolica, T. (2013). Dynamic Panel data model for capitak structure of listed companies in Set. Journal of Asia Pacific Innovation and Technology Management, 3, $1-13$.

Wang, Y., Sun, Y., \& Lv, Q. (2010). Empirical study on the debt maturity structure based on macroeconomic variables. International Journal of Business and Management, 5(12), 135-140. 